\title{
A Comparative Study of Congenital Toxoplasmosis between Public and Private Hospitals from Uberlândia, MG, Brazil
}

\author{
Gesmar Rodrigues Silva Segundo, Deise Aparecida Oliveira Silva, José Roberto Mineo, \\ Marcelo Simão Ferreira $*{ }^{+}$
}

\begin{abstract}
Laboratório de Imunoparasitologia, Instituto de Ciências Biomédicas *Serviço de Moléstias Infecciosas, Departamento de Clínica Médica, Faculdade de Medicina, Universidade Federal de Uberlândia, Av. Pará 1720, Campus Umuarama, 38400-902

Uberlândia, MG, Brasil
\end{abstract}

\begin{abstract}
The main purpose of the present study was to examine if there is difference in terms of incidence rates of congenital toxoplasmosis among populations assisted in public and private hospitals from Uberlândia, state of Minas Gerais, Brazil. A total of 805 serum samples from cord blood were collected, being 500 from public hospital and 305 from private hospital, and all patients answered a questionnaire about pregnancy and newborns. An indirect enzyme linked immunosorbent assay (ELISA) was performed to detect IgG antibodies to Toxoplasma gondii and the positive samples were retested to verify the presence of specific IgM and IgA antibodies in a capture ELISA. We found significant differences among data from both hospitals with respect to maternal age, origin city, gestational age, number of visits to physicians during pregnancy, type of delivery, and birth weight. Seroprevalence of IgG antibodies against T. gondii for patients from public and private hospitals was $57.6 \%$ and $41.9 \%$ respectively, and this difference was statistically significant $(P<0.0001)$. In addition, the frequency of congenital toxoplasmosis measured by the presence of IgM and/or IgA antibodies toward T. gondii was exclusively located in samples from public hospital (0.8\%), and no positive sample was seen in private hospital (0\%). Considering that almost all babies suffering from congenital toxoplasmosis, if undiagnosed and untreated, will develop visual or neurological impairments by adulthood, the results presented herein emphasized the importance to accomplish screening programs for toxoplasmosis during pregnancy, particularly in the public hospitals, due to the expressive rate of congenital disease showed in the patients attended at these centers.
\end{abstract}

Key words: toxoplasmosis - congenital infection - public hospital - private hospital - gestational screening - Uberlândia - Brazil

Since the initial identification of Toxoplasma gondii, this parasite was associated with infections in animals and humans (Remington et al. 2001). Infection of immunocompetent hosts is often asymptomatic or associated with a mild, self-limited illness. However, immunosuppressed individuals like fetuses, organ graft recipients or patients with acquired immunodeficiency syndrome (AIDS) develop a severe disease (Feigin \& Cherry 1998).

Although T. gondii has a worldwide distribution, infection is more prevalent in some regions in Europe and parts of Caribbean and South America (Lebech et al. 1999). The prevalence of specific antibodies to $T$. gondii is directly proportional to the population age, indicating that infection is acquired throughout life (Remington et al. 2001). Human infection may be acquired in several ways, such as the ingestion of oocysts from contaminated soil or water, the direct contact or consumption of unwashed vegetables, the ingestion of raw or under-cooked meat containing viable tissue cysts, and less frequently, the direct recipient of tissue or blood from other contaminated humans and the vertical transmission from acutely infected mothers (Feigin \& Cherry 1998).

${ }^{+}$Corresponding author. Fax: +55-34-3218.2333. E-mail: mferreira@nanet.com.br

Received 5 September 2003

Accepted 18 December 2003
Vertical transmission is responsible for congenital toxoplasmosis. The materno-fetal transmission rates vary according to gestational age at the time of maternal infection (Edwards 2002). Maternal infection in the first trimester of gestation results in a transmission rate of $10-15 \%$, which rises up to $68 \%$ in the third trimester (Thulliez et al. 1992). The antiparasitic treatment during pregnancy can reduce transmission or sequelae in the fetus, therefore, it is very important to identify this disease as soon as possible (Fulton et al. 1999b). Congenital toxoplasmosis is asymptomatic in the majority of infants at birth. However, if undiagnosed and untreated, almost all babies infected will develop visual or neurological impairments by adulthood (Mcauley et al. 1994). Because this, systematic screening programs are the only possible way to detect infection of newborns at early stages (Lebech \& Petersen 1995). Until now, there is no global consensus about the better screening program (Lopez et al. 2000).

France and Austria have screened for acute toxoplasmosis during pregnancy since 1975 . Other countries, such as Germany, Switzerland, Italy, and Belgium make an extensive screen in pregnancy, but it is not accomplished nationwide (Lebech et al. 1999). In the New England area, US, and Denmark, a neonatal screening has been used in the last years (Lebech et al. 1999, Piper \& Wen 1999, Lopez et al. 2000), and since 1998, the Center of Disease Control and Prevention (CDC) has studied the necessary requirements and what would be the better screening program for congenital toxoplasmosis (Lopez et al. 2000). 
In developing countries located in South America there are few studies concerning this issue. In Brazil, studies show a prevalence rate of $T$. gondii-specific antibodies ranging from 50 to $76 \%$ (Ricciardi et al. 1978, Souza et al. 1987, Borges et al. 1997, Andrade et al. 2001), while the occurrence of congenital toxoplasmosis ranged from 0.2 to $2 \%$ (Silveira et al. 1988, Reiche et al. 2000, Neto et al. 2000). There is still a great variation within the population in this country, with a marked difference in socioeconomic levels and conditions of health assistance, already described as important factors in the epidemiology of toxoplasmosis (Jara et al. 2001).

The aim of this study was to investigate the occurrence of congenital toxoplasmosis in Uberlândia, Minas Gerais, and to analyze differences among populations assisted by public and private hospitals.

\section{PATIENTS AND METHODS}

Patients and serum samples - All infants that were born in the Hospital e Maternidade Santa Clara (HMSC), a private hospital, and in the Hospital de Clínicas da Universidade Federal de Uberlândia (HC-UFU), a public hospital, from January to August 2002, were admitted for the study. Newborns were excluded if serum samples had been incorrectly collected or if the parents did not accept to participate of the study. A total of 805 infants filled inclusion criteria, 305 from HMSC and 500 from HC-UFU. Cord blood samples of infants at birth were collected in 5 $\mathrm{ml}$ tubes (Vacutainer, Precision Glide/Becton Dickson Vacutainer System, NJ, US), then centrifuged and all available sera were stored at $-20^{\circ} \mathrm{C}$, in duplicate vials, until being analyzed serologically. A questionnaire about maternal age, origin city, gestational age, number of visits to the physician during pregnancy, was applied to the parents, and questions related to sex and weight of infants, as well as type of delivery, were answered after birth.

This study was submitted to and approved by the Ethical Committees of both hospitals.

Serological assays - All serum samples were tested in ELISA (enzyme-linked immunosorbent assay) to detect IgG antibodies to T. gondii (Mineo et al. 1980). Capture ELISA assays to detect specific IgM or IgA antibodies in IgG-positive sera was also carried out as previously described (Pinon et al. 1986, Silva et al. 2002).

IgG ELISA - An ELISA was carried out to detect human IgG anti-T. gondii as described by Mineo et al. (1980), with modifications. Briefly, microtiter plates (Montegrotto, Palermo, Italy) coated with $T$. gondii soluble antigen (10 $\mu \mathrm{g} / \mathrm{ml}$ ) were incubated with sera diluted $1: 16$ in $0.01 \mathrm{M}$ phosphate buffered saline $\mathrm{pH} 7.2$ (PBS) plus $0.05 \%$ Tween 20 (PBS-T) containing 5\% non-fat milk (PBS-T-M) as diluent buffer for $1 \mathrm{~h}$ at $37^{\circ} \mathrm{C}$. After repeated washing, peroxidasegoat anti-human IgG (Sigma Chemical, Saint Louis, US) diluted 1:2000 in PBS-T-M was added and incubated for $1 \mathrm{~h}$ at $37^{\circ} \mathrm{C}$. The assay was developed by adding the enzyme substrate orthophenylenediamine at $0.5 \mathrm{mg} / \mathrm{ml}$ in $0.1 \mathrm{M}$ citrate-phosphate buffer ( $\mathrm{pH} 5.8$ ) and $0.012 \% \mathrm{H}_{2} \mathrm{O}_{2}$ (OPD, Merck, Rio de Janeiro, Brazil). After incubation for $10 \mathrm{~min}$ at room temperature, the optical density (OD) was read at $492 \mathrm{~nm}$ (Titertek Multiskan, Flow Laboratories, US). Controls on each plate included serum control (PBS-
T-M substituting sera) and reference sera. The cut off for a positive test was determined as the mean OD for the negative control plus three standard deviations. Antibody titers were arbitrarily expressed as ELISA Indexes (EI) according to Silva et al. (2002), as follows: $\mathrm{EI}(\%)=\left(\mathrm{OD}_{\text {sample }} /\right.$ $\left.\mathrm{OD}_{\text {cut off }}\right) \times 100$, where values of $\mathrm{EI} \geq 100$ were considered as positive titers.

Capture ELISA IgM and IgA - Optimal conditions for $\operatorname{IgM}$ or IgA capture ELISA were established in preliminary experiments through block titration of the reagents (capture antibodies, sera, antigen, and conjugate) as previously described by Silva et al. (2002). Microtiter plates (Immulon 2, Dynex Technologies, US) were coated with capture antibodies (goat anti-human IgM, $\mu$-chain specific or goat anti-human IgA, $\alpha$-chain specific; Sigma Aldrich, Saint Louis, US) at $5 \mu \mathrm{g} / \mathrm{ml}$ in $0.06 \mathrm{M}$ carbonate buffer, $\mathrm{pH} 9.6$, overnight at $4^{\circ} \mathrm{C}$. Next, plates were blocked with PBS-T-M for $30 \mathrm{~min}$ at $37^{\circ} \mathrm{C}$. Subsequent steps were carried out using PBS-T-M as diluent buffer, and washing with PBS-T was done between the steps of the reaction. Plates were incubated with sera diluted 1:16 for $2 \mathrm{~h}$ at $37^{\circ} \mathrm{C}$. Then, $T$. gondii excreted-secreted antigen $(5 \mu \mathrm{g}$ of protein/well) obtained as described by Decoster et al. (1988) was added and incubated for $2 \mathrm{~h}$ at $37^{\circ} \mathrm{C}$. The bound antigen was detected with a peroxidase-rabbit $\mathrm{F}\left(\mathrm{ab}^{\prime}\right) 2$ antiT. gondii, prepared as described by Wilson and Nakane (1978), diluted $1: 50$ and incubated for $1 \mathrm{~h}$ at $37^{\circ} \mathrm{C}$. The assay was developed by adding the enzyme substrate $(0.1 \mathrm{M}$ citric acid, $0.2 \mathrm{M}$ sodium phosphate, $0.01 \mathrm{M} 2,2$ '-azino-di3 -ethylbenzthiazoline-6-sulfonic acid-ABTS, $0.03 \%$ $\mathrm{H} 2 \mathrm{O} 2$ ), and the $\mathrm{OD}$ was read at $405 \mathrm{~nm}$. Controls on each plate included serum control (PBS-T substituting sera), and reference sera. Antibody titers were arbitrarily expressed as EI, as described for IgG-ELISA.

Statistical analysis - Statistical analysis consisted of determinations of geometric means with $95 \%$ confidence intervals and the differences between the means were analyzed by the Mann-Whitney test. Comparisons between proportions were analyzed by the Chi-square test. Values of $P<0.05$ were considered as statistically significant.

\section{RESULTS}

Data about clinic parameters showed statistically significant differences between the two hospitals with respect to maternal age, origin city, gestational age, number of visits to physicians during pregnancy, type of delivery and birth weight, indicating better quality in assistance to health during pregnancy among population assisted by the private hospital (Table I).

Results of serological assays for toxoplasmosis are demonstrated in Table II. Prevalence of IgG antibodies to T. gondii in cord blood was $51.6 \%$ in both populations. In HC-UFU, seroprevalence was $57.6 \%$ while in HMSC was $41.9 \%$. Four patients showed $\operatorname{IgM}$ antibodies anti-T. gondii, resulting in a rate of $0.5 \%$ in live newborns, and all of these infants were born in the public hospital. Only two of the four infants also had IgA antibodies anti-T. gondii concomitantly. There were statistically significant differences between populations assisted in both hospitals regarding the seroprevalence for $\mathrm{IgG}$, but there was 
no significant difference related to specific $\operatorname{IgM}$ or $\operatorname{Ig} \mathrm{A}$ antibodies.

The serological profile of patients with congenital toxoplasmosis is demonstrated in the Table III. Clinical presentation of congenital toxoplasmosis included chorioretinitis (two infants), microcephaly and hepatomegaly (one infant), and asymptomatic (one infant). Only the two patients with chorioretinitis were positive for IgA antibodies to T. gondii. All patients with congenital toxoplasmosis received treatment based on sulfadiazine, pirimetamine and folinic acid.

\section{DISCUSSION}

There was marked difference among mothers assisted in public and private hospitals. Maternal age, number of pre-terms and post-terms, birth weight, and number of visits to the physicians during pregnancy showed better quality in assistance to health during pregnancy in the private hospital.
Seroprevalence for toxoplasmosis was $51.6 \%$, and this is similar to other studies carried out in Brazil, with rates ranging from 50 to $76 \%$ (Ricciardi et al. 1978, Souza et al. 1987, Borges et al. 1997, Andrade et al. 2001). The detection of IgG antibodies to T. gondii in other countries is variable: Finland (18.9\%), Denmark (28\%), US (38.5\%), France (80\%), as previously reported (Lappalainen et al. 1993, Lebech et al. 1999, Piper \& Wen 1999). There was significant difference in seroprevalence for $\mathrm{IgG}$ antibodies to $T$. gondii between the two populations studied, indicating that people assisted by public hospital have larger exposure to the parasite.

The occurrence of congenital toxoplasmosis was $0.5 \%$, and it was similar with few studies in Brazil, which showed rates of congenital toxoplasmosis ranging from 0.2 to $2 \%$ (Silveira et al. 1988, Reiche et al. 2000, Neto et al. 2000). However, all cases with congenital infection were from HC-UFU, whose isolated rate was of $0.8 \%$. In the present study, a higher rate of congenital infection was found in

TABLE I

Profile of population assisted by public and private hospitals in Uberlândia, Brazil, 2002

\begin{tabular}{lll}
\hline Population data & Public hospital & Private hospital \\
\hline Maternal age (SD) $^{a}$ & 23.9 years (5.49) & 27.7 years (5.38) \\
Origin city $^{c}(\%)^{a}$ & $64(12.9)$ & $11(3.6)$ \\
Gestational age (SD) $^{a}$ & 38.7 weeks (2.31) & 38.5 weeks (1.1) \\
Visits to physicians (SD) $^{a}$ & 6.5 visits (1.99) & 10.25 visits (2.39) \\
Weight birth (SD) $^{b}$ & $3,029.19 \mathrm{~g}(584.30)$ & $3,185.28 \mathrm{~g}(460.90)$ \\
Male (\%) $_{\text {Natural delivery (\%) }}{ }^{a}$ & $259(51.8)$ & $154(50.5)$ \\
\hline
\end{tabular}

$a$ : $P<0.0001$ : significant difference between public and private hospital; $b: P=0.0002$ : significant difference between public and private hospital; $c$ : origin from other cities except Uberlândia; SD: standard deviation

TABLE II

Results of serological assays for toxoplasmosis in population assisted by public and private hospitals in Uberlândia, Brazil, 2002

\begin{tabular}{lccc}
\hline Assay & $\begin{array}{c}\text { Public hospital } \\
\mathrm{n}=500\end{array}$ & $\begin{array}{c}\text { Private hospital } \\
\mathrm{n}=305\end{array}$ & $\begin{array}{c}\text { Total } \\
\mathrm{n}=805\end{array}$ \\
\hline $\begin{array}{l}\text { IgG- ELISA (EI) } \\
\text { T. } \text { gondii } \text { positive (EI }>\text { 100) }^{a}\end{array}$ & $288(57.6 \%)$ & $128(41.9 \%)$ & $416(51.6 \%)$ \\
$\begin{array}{l}\text { IgM and/or IgA capture ELISA } \\
\text { T. } \text { gondii } \text { positive (EI }>\text { 100) }\end{array}$ & $4(0.8 \%)$ & $0(0 \%)$ & $4(0.5 \%)$ \\
\hline
\end{tabular}

a: $P<0.0001$ : significant difference between public and private hospital; ELISA reactivity indices: (OD serum sample/OD cut off) $\mathrm{x} 100$; positive if $\mathrm{EI}>100$

TABLE III

Serological profile and clinic alterations in infants with congenital toxoplasmosis in Uberlândia, Brazil, 2002

\begin{tabular}{|c|c|c|c|c|}
\hline Patients & $\begin{array}{l}\text { IgG ELISA } \\
\quad(\mathrm{EI})^{a}\end{array}$ & $\begin{array}{l}\text { IgA ELISA } \\
(\mathrm{EI})^{a}\end{array}$ & $\begin{array}{l}\text { IgM ELISA } \\
(\mathrm{EI})^{a}\end{array}$ & Clinical alterations \\
\hline 1 & 521 & 155 & 308 & Chorioretinitis \\
\hline 2 & 419 & 47 & 238 & Hepatomegaly and microcephaly \\
\hline 3 & 257 & 82 & 151 & Asymptomatic \\
\hline 4 & 949 & 165 & 290 & Chorioretinitis \\
\hline
\end{tabular}

$a$ : ELISA reactivity indices: (OD serum sample/OD cut off) x 100; consider positive if EI > 100 
Uberlândia, Brazil, when compared with other studies (Eaton et al. 1996, Lebech et al. 1999, Lopez et al. 2000, Malgorzata et al. 2001) performed in several countries, such as US (0.01 to $0.10 \%)$, Denmark $(0.03 \%)$, Sweden $(0.0073 \%)$, United Kingdom, $(0.1 \%)$, and Poland $(0.1 \%)$.

Clinical alterations found in patients with congenital toxoplasmosis were chorioretinitis, microcephaly, and hepatomegaly, and these are similar to those described in literature (Desmonts \& Couvreur 1974). Interestingly, early chorioretinitis was found only in patients with detectable IgA antibodies to T. gondii. The relevance of the detection of the $\operatorname{IgA}$ isotype in congenital toxoplasmosis has been recently emphasized because the presence of anti- $T$. gondii specific IgM throughout the entire pregnancy did not characterize acute phase infection and, therefore, complementary tests are necessary (Spalding et al. 2003). In another study, other investigators have quantified the risk of transmission of toxoplasmosis infection, not only in cases of seroconversion, as reported previously, but also in infections defined as probable or possible based on presence of IgM and/or IgA and with medium-high IgG levels (Mombro et al. 2003). Probable infections in the second trimester of pregnancy carries the same risk of transmission as seroconversions and pregnant women and their newborns in these cases should undergo the same diagnostic and therapeutic approach. It was suggested that newborns of mothers with certain and probable infection must be carefully observed and undergo clinical and serological testing to identify and treat the infection as soon as possible. In the case of possible or unlikely maternal infection, serological testing at longer intervals is nevertheless advisable without the need for treatment (Mombro et al. 2003). For neonatal diagnosis of congenital toxoplasmosis, IgE was less informative than $\operatorname{IgM}$ and $\operatorname{Ig} \mathrm{A}$ (sensitivities, 59.5, 64.3, and 76.2\%, respectively) and had a specificity of $91.9 \%$. Nevertheless, simultaneous measurement of the three isotypes at birth improved the diagnostic yield to $81 \%$ relative to the combination of $\operatorname{IgA}$ and $\operatorname{IgM}$. Emergence of specific IgE during postnatal treatment for congenital toxoplasmosis is a sign of poor adherence or inadequate dosing (Foudrinier et al. 2003).

Three factors that influence primo-infection in pregnant women should be taken into consideration in order to explain the prevalence rate in a given population. First, the prevalence of infection in the community; second, the frequency of probable contacts with sources of infection; and third, the number of women with childbearing age who have not had primoinfection yet (Remington et al. 2001). There are some considerations about the epidemiology of toxoplasmosis for adopting a screening program. In countries with high seropositivity in the population, the majority of pregnants are positive IgG, and the remaining seronegative ones have a high risk of infection during pregnancy. As only few women are negative, the cost of serological tests during pregnancy is not high. On the other hand, in population with low prevalence of toxoplasmosis, the majority of pregnants are seronegative, but they have a low risk of infection because the contact with infection forms is rare. In this case, there is an expensive cost with repeated serological tests during pregnancy, and the neonatal screening seems an attractive and costeffective alternative method (Lebech et al. 1999).

As in France and Austria, Brazil has some regions with high prevalence of toxoplasmosis in their communities. Thus, it is necessary to accomplish active seeking during all pregnancy for toxoplasmosis through serological tests. In negative cases, serology has to be repeated trimestrally up to one month after delivery (Foulon et al. 1999a, Chemla et al. 2002). If seroconversion occurs during gestational period, it is necessary to treat mothers to reduce transmission or sequelae in infants (Foulon et al. 1999b). A multicenter study emphasized the orientation about transmission forms of disease and how to avoid the infection to mothers in order to decrease the acute maternal infection and consequently, the congenital infection (Cook et al. 2000).

Taking together, the results presented herein emphasize the importance to accomplish systematic serological screening programs during pregnancy in order to prevent the occurrence of elevated number of infants with congenital toxoplasmosis. Specific focus should be devoted in populations with marked difference in socio-economic levels and health assistance, where pregnant women used to look for public hospitals usually at the time of delivery.

\section{REFERENCES}

Andrade GMQ, Carvalho AL, Carvalho IR, Mello BF, Tibúrcio FR, Castro FC 2001. Toxoplasmose na gestante e no recém nascido - Estudo de 86 pares de mãe-filho atendidos no período de 1996-99 no ambulatório de infectologia pediátrica do HC-UFMG. Rev Med Minas Gerais 11: 202-207.

Borges AS, Fonseca AM, Ferreira MS, Silvestre MTA, Valente SRG 1997. Anticorpos anti T. gondii nos doadores de sangue do Hemocentro Regional de Uberlândia, MG. Braz J Infect Dis 1: s88.

Chemla C, Villena DA, Hornoy P, Dupoy D, Leroux B, Bory JP, Pinon JM 2002. Preconception seroconversion and maternal seronegativity at delivery do not rule out the risk of congenital toxoplasmosis. Clin Diag Lab Immunol 9: 489-490.

Cook AJ, Gilbert RE, Buffolano W, Zufferey J, Petersen E, Jenum PA, Foulon W, Semprini AE, Dunn DT 2000. Sources of Toxoplasma infection in pregnant women: european multicentre case control study. BMJ 321: 142-147.

Decoster A, Darcy F, Capron A 1988. Recognition of Toxoplasma gondii excreted and secreted antigens by human sera from acquired and congenital toxoplasmosis: identification of markers of acute and chronic infection. Clin Exp Immunol 73: 376-382.

Desmonts G, Couvreur J 1974. Congenital toxoplasmosis. A prospective study of 378 pregnancies. New England J Med 290: 1110-1116.

Eaton RB, Petersen E, Sepannen H, Tuuminen T 1996. Multicenter evaluation of a fluorimetric enzyme capture assay to detect Toxoplasma-specific immunoglobulin $\mathrm{M}$ in dried blood filter paper specimens from newborns. J Clin Microbiol 4: 3147-3150.

Edwards ME 2002. Fungal and protozoan infections. In AA Fanaroff, RJ Martin (eds) Neonatal-Perinatal Medicine, Diseases of Fetus and Infant, 7th ed., Mosby, St Louis, p. 745-755.

Feigin RD, Cherry JD 1998. Textbook of Pediatric Infectious Diseases, 4th ed., WB Saunders, Philadelphia, 2921 pp.

Foudrinier F, Villena I, Jaussaud R, Aubert D, Chemla C, 
Martinot F, Pinon JM 2003. Clinical value of specific immunoglobulin $\mathrm{E}$ detection by enzyme-linked immunosorbent assay in cases of acquired and congenital toxoplasmosis. J Clin Microbiol. 41: 1681-1686.

Foulon W, Pinon JM, Stray-Pedersen B, Pollak A, Lappalainen M, Decoster A, Villena I, Jenum PA, Hayde M, Naessens A 1999a. Prenatal diagnosis of congenital toxoplasmosis: a multicenter evaluation of different diagnostic parameters. Am J Obstet Gynecol 181: 843-847.

Foulon W, Villena I, Stray-Pedersen B, Decoster A, Lappalainen M, Pinon JM, Jenum PA, Hedman M, Naessens A 1999b. Treatment of toxoplasmosis during pregnancy: a multicenter study of impact on fetal transmission and children's sequelae at age 1 year. Am J Obstet Gynecol 180: 410-415.

Jara M, Hsu HW, Eaton RB, Demaria Jr A 2001. Epidemiology of congenital toxoplasmosis identified by population-based newborn screening in Massachusetts. Pediatr Infect Dis $J$ 20: 1132-1135.

Lappalainen M, Koskela P, Koskiniemi M, Ammala P, Hilesmaa V, Terano K, Remington JS, Hedman K 1993. Toxoplasmosis acquired during pregnancy: improved serodiagnosis based on avidity of IgG. J Infect Dis 167: 694-697.

Lebech M, Petersen E 1995. Detection by enzyme immunosorbent assay of Toxoplasma gondii IgG antibodies in dried blood spots on PKU-filter paper from newborns. Scand J Infect Dis 27: 259-263.

Lebech M, Andersen O, Christensen NC, Hertel J, Nielsen HE, Peitersen B, Rechnitzer C, Larsen SO, Nogaard-Pedersen B, Petersen E 1999. Feasibility of neonatal screening for Toxoplasma infection in the absence of prenatal treatment. Lancet 353: 1834-1837.

Lopez A, Dietz VJ, Wilson M, Navim TR, Jones JL 2000. Preventing congenital toxoplasmosis. Morb Mort Week Report 49: 57-71.

Malgorzata P, Petersen E, Szczapa J 2001. Prevalence of congenital Toxoplasma gondii infection from the Poznan region of Poland: validation of a new combined enzyme immunoassay for Toxoplasma gondii-specific immunoglobulin A and immunoglobulin M antibodies. J Clin Microbiol 39: 1912-1916.

Mcauley J, Boyer KM, Patel D, Mets M, Swisher C, Roizen N, Wolters C, Stein L, Stein M, Schey W 1994. Early and longitudinal evaluations of treated infants and children and untreated historical patients with congenital toxoplasmosis - The Chicago collaborative treatment trial. Clin Infect Dis 18: 38-72.

Mineo JR, Camargo ME, Ferreira AW 1980. Enzyme-linked immunosorbent assay for antibodies to Toxoplasma gondii polysaccharides in human toxoplasmosis. Infect Immun 27: $283-287$.

Mombro M, Perathoner C, Leone A, Buttafuoco V, Zotti C, Lievre MA, Fabris C 2003. Congenital toxoplasmosis: assessment of risk to newborns in confirmed and uncertain maternal infection. Eur J Pediatr 162: 703-706.

Neto EC, Anele E, Rubim R, Brites A, Schulte J, Becker D,
Tuuminen T 2000. High prevalence of congenital toxoplasmosis in Brazil estimated in a 3 year prospective neonatal screening study. Int J Epidemiol 29: 941-947.

Pinon JM, Thoannes H, Pouletty PH, Poirriuz J, Damiens J, Pelletier P 1986. Detection of IgA specific for toxoplasmosis in serum and cerebrospinal fluid using a non-enzymatic IgA capture assay. Diag Immunol 4: 223-227.

Piper JM, Wen TS 1999. Perinatal cytomegalovirus and toxoplasmosis: challenges of antepartum therapy. Clin Obstet Gynecol 42: 81-96.

Reiche EMV, Morimoto HK, Faria GN, Hisatsugu KR, Geller L, Gomes ACLF, Inoue HY, Rodrigues G, Matsuo T 2000. Prevalência de tripanossomíase americana, sífilis, toxoplasmose, rubéola, hepatite $\mathrm{B}$, hepatite $\mathrm{C}$ e da infecção pelo vírus da imunodeficiência humana, avaliada por intermédio de testes sorológicos, em gestantes atendidas no período de 1996 a 1998 no Hospital Universitário Regional Norte do Paraná (Universidade Estadual de Londrina, Paraná, Brasil). Rev Soc Bras Med Trop 33: 519-527.

Remington JS, McLeod R, Thulliez P, Desmonts G 2001. Toxoplasmosis. In JS Remington, JO Klein (eds), Infectious Diseases of Fetus and Newborn Infant, 5th ed., WB Saunders, Philadelphia, p. 205-346.

Ricciardi ID, Sabroza PC, Sandoval ED, Mayrink W 1978. Seroepidemiological study in the prevalence of human toxoplasmosis in Brazil. Rev Microbiol 9: 181-187.

Silva DAO, Silva NM, Mineo TWP, Pajuaba Neto A, Ferro EAV, Mineo JR 2002. Heterologous antibodies to evaluate the kinetics of the humoral immune response in dogs experimentally infected with Toxoplasma gondii $\mathrm{RH}$ strain. Vet Parasitol 3: 181-195.

Silveira C, Belfort R, Burnier M, Nussenblatt R 1988. Acquired toxoplasmic infection as the cause of toxoplasmic retinochorioditis in families. Am J Ophthalmol 106: 362-364.

Souza WJS, Coutinho SG, Lopes CWG, Santos CS, Neves NM, Cruz AM 1987. Epidemiological aspects of toxoplasmosis in school children residing in localities with urban or rural characteristics within the city of Rio de Janeiro, Brazil. Mem Inst Oswaldo Cruz 82: 475-482.

Spalding SM, Amendoeira MR, Ribeiro LC, Silveira C, Garcia AP, Camillo-Coura L 2003. Prospective study of pregnants and babies with risk of congenital toxoplasmosis in municipal district of Rio Grande do Sul. Rev Soc Bras Med Trop 36: 483-491.

Thulliez P, Daffos F, Forrestier F 1992. Diagnosis of Toxoplasma infection in the pregnant woman and the unborn child: current problems. Scand J Infect Dis 84 (Suppl.): 1822.

Wilson MB, Nakane PK 1978. Recent developments in the periodate method of conjugating horseradish peroxidase (HRPO) to antibodies. In W Knapp, K Holubar, G Wick (eds), Immunofluorescence and Related staining Techniques, Elsevier North Holland Biomedical Press, Amsterdan, p. 215-224. 